\title{
Microbiology of composting pig waste: Comparison of vermicomposting and open heap techniques
}

\author{
Ogefere, H. O. ${ }^{1,3, \star}$, Ogbimi, A. O. ${ }^{2}$ and Omoregie, R. ${ }^{3}$ \\ ${ }^{1}$ Department of Medical Laboratory Sciences, School of Basic Medical Sciences, College of Medical Sciences, \\ University of Benin, Benin City, Edo State. \\ ${ }^{2}$ Department of Microbiology, Faculty of Life Sciences, University of Benin, Benin City, Edo State. \\ ${ }^{3}$ School of Medical Laboratory Science, University of Benin Teaching Hospital, P.M.B. 1111, Benin City, Edo State, \\ Nigeria. \\ E-mail: helenogefere@yahoo.com
}

Received 7 May 2009; received in revised form 13 July 2009; accepted 13 July 2009

\begin{abstract}
Against the background of an effective waste management, microbiological studies of composting pig waste were investigated. Freshly deposited excreta from confined pigs in a private pig farm in Benin City, Edo State, Nigeria were composted by two aerobic methods - vermicomposting and open heap. Microbial (bacterial and fungal) counts and characterization were carried out periodically within the 40 weeks of composting, using standard techniques. The results showed that only duration of composting significantly $(p<.0 .05)$ affected microbial counts as the counts decreased from the initial value at week zero to much lower value at week 40 . A total of 274 bacterial and fungal isolates were recovered from the composting waste and majority $(60.58 \%)$ were isolated from the open heap. Bacillus subtilis, Pseudomonas aeruginosa and Aspergillus flavus were the predominant isolates recovered (9.49\% each), and were the only isolates recovered throughout the period of composting irrespective of the composting technique. Staphylococcus aureus and Salmonella typhimurium were the least isolated (1.09\% each). Vermicomposting technique was recommended on health and environmental grounds.
\end{abstract}

Keywords: composting, microbiological examination, open heap composting, vermicomposting

\section{INTRODUCTION}

Compost is the product of aerobic process during which microganisms play an important role. Essentially, the microgranisms decompose the organic matter into a stable amendment for improving soil quality and fertility (Borken et al., 2002; Tiquia, 2005). A number of biological wastes can be used for composting which include municipal solid wastes, animal and human excreta, (Ryckeboer et al., 2003; Tiquia, 2005). The importance of composting include production of organic manure, land scaping and restoration of denuded areas such as areas of oil spillage (Jarvis et al., 1988; Atkinson et al., 1996; Guibileo et al., 1998).

Although several reports are available concerning the composition and dynamics of the microflora during the composting of these wastes (Ryckeboer et al., 2003), little is known about the microbial diversity during the composting of the organic fraction of the waste. Monitoring of the microbial succession is important in the effective management of the composting process as microganisms play important roles in the process and the appearance of some microgranisms reflects the quality of maturity of compost (Ishii et al., 2000).

The ability of some earthworm species to compost a wide range of organic residues such as sewage sludge, animal wastes, crop residues and industrial refuse have been established (Atiyeh et al., 2002). Vermicomposts are finely divided peat-like manure materials with high porosity, aeration, drainage and water-holding capacity. This is because they have large surface area, providing strong absorption capacity and retention of nutrients (Ogefere, 2007).

It has been reported that the operating strategies used during composting of spent pig litter would influence the composting process and time of maturation (Tiquia, 2005). This study therefore is aimed to compare two composting techniques-vermicomposting and open heap technique, microbiologically.

\section{MATERIALS AND METHODS}

\section{Collection and processing of samples}

"Freshly" voided excreta of confined pigs in Agricultural Development Programme Private pig farm in Oko village near Benin City, Edo State, Nigeria were used for this study. The aerobic composting of $300 \mathrm{~kg}$ pig waste was performed in three perforated (44 holes of $0.5 \mathrm{~cm}$ diameter) plastic drum $(1.0 \times 0.8 \mathrm{~m})$ containers with lid. Each of the three composting vessels was three quarter filled with $100 \mathrm{~kg}$ of the pig waste. These vessels, as 
reported by Atiyeh et al., (2002), had their content unstirred but each had 30 earthworms (Lumbricus terrestis), added (11 juveniles and 19 adults). This set of vessels with earthworms was labeled vermicomposted vessels. In a second method, described earlier (Inbar et al., 1993), triplicate of $100 \mathrm{~kg}$ pig waste were left as open heap on a cleared ground. All vessels (placed $5 \mathrm{~m}$ apart) as well as the open heaps ( $5 \mathrm{~m}$ apart) of waste were placed on the floor of a cleared netted surrounding. The heaps were not watered at interval and were not covered both during the day and at night, throughout the composting period.

These wastes were allowed to compost for 40 weeks at atmospheric temperature of $29 \pm 3^{\circ} \mathrm{C}$. At week $0,1,2$, $4,6,8,10,14,18,20,24,30$ and 40 , the temperature of each composting vessel was taken. Using aseptic condition throughout, sterile universal container (Sterilin, Spain) three quarter filled with composting waste was removed from each vessel and heap and transported to the laboratory in ice packs and analysed microbiologically to determine the total viable bacterial and fungal counts, and types of bacteria and fungi present.

\section{Microbiological examination}

The pour plate method for bacterial enumeration as earlier described (Cruickshank et al., 1975) was employed. The pig waste $(10 \mathrm{~g})$ was dissolved in $100 \mathrm{~mL}$, sterile quarter strength Ringer's solution (Oxoid, England) and diluted serially. For bacterial counts, appropriate dilutions were incorporated in nutrient agar (Lab 8: LAB $M^{T M}$ International diagnostic group PLC, UK), amended with 20 $\mu \mathrm{g} / \mathrm{mL}$ nystatin to inhibit fungal growth. Plates were prepared in triplicates and incubated at $30 \pm 2{ }^{\circ} \mathrm{C}$ and $37{ }^{\circ} \mathrm{C}$ for $24 \mathrm{~h}$. For fungal counts, appropriate dilutions were incorporated in Sabourand dextrose agar $(\mathrm{Cm} 41$ Oxoid, England) amended with $20 \mu \mathrm{g} / \mathrm{mL}$ gentamicin to inhibit bacterial growth. Plates were prepared in triplicates and incubated at room temperature $\left(30 \pm 2{ }^{\circ} \mathrm{C}\right)$ for 2 to 5 days. Emergent bacterial and fungal colonies were enumerated with a colony counter (Gallenkamp, England) and the mean counts in each waste sample obtained. Counts were quantified, as colony forming units $/ \mathrm{mL}$.

From the original composting pig waste Ringer's mixture, subculture were made on MacConkey agar (Oxoid, England), nutrient agar with nystatin, deoxycholate citrate agar (Biotic Laboratories, U.K.) and Sabouraud dextrose agar with gentamicin. All plates were incubated at $30 \pm 2{ }^{\circ} \mathrm{C}$ and at $37^{\circ} \mathrm{C}$ for $24 \mathrm{~h}$ apart from the Sabourand dextrose agar with gentamicin which were incubated for 2 to 5 days.

The emergent bacterial colonies were identified according to criteria of Barrow and Feltham (2003), while the fungi isolates were identified according to criteria of Rippon (1974) and Lodder (1971).

Parametric data were analysed manually, using twoway ANOVA without replication.

\section{RESULTS}

The bacterial and fungal counts followed the same pattern throughout the composting period and only duration of composting significantly affected microbial counts $(p<0.05)$ as both bacterial and fungal counts increased initially and then continue to decrease till the end of the composting period (Table 1)

The frequency of microbial isolates recovered in this study is shown in Table 2. A total of 274 microbial isolates were recovered and open heap (60.58\%) yielded more isolates than vermicromposting (39.42\%). $P$. aeruginosa, $B$. subtilis and $A$. flavus were the most prevalent isolates $(9.49 \%$ each) while $S$. typhimurium and $S$. aureus were the least isolated (1.09\% each).

Microbial succession during vermicomposting and open heap techniques are shown in Tables 3 and 4 respectively. Although, no definite pattern was observed, $P$. aeruginosa, $B$. subtilis and $A$. flavus were the only isolates recovered throughout the composing period irrespective of the composting technique.

\section{DISCUSSION}

It is a well known fact that biologically processed organic manures are better than inorganic artificial fertilizers (University System News, 1994). One of the front liners in the world today is environmental protection and waste management. In addition, in Nigeria, the present government is encouraging agriculture and local production as against importation. One of the ways to merge these is the conversion of organic wastes to manure for agricultural use. During composting, the microorganisms use the organic matter as a food source. The process produces heat, carbon dioxide, water vapour and humus as a result of growth and activities of microorganisms (Tiquia, 2005). Monitoring of the microbial succession is important in the effective management of the composting process as microorganisms play key roles in the process and the appearance of some microorganisms reflects the quality of maturing compost (Ryckeboer et al., 2003). Thus, this study is aimed at determining microbial succession during pig composting using two techniques.

The method of composting did not affect microbial counts $(p>0.05)$. Microbial count were only significantly $(p<0.05)$ affected by duration of composting (Table 1$)$. In both techniques there was an initial increase in microbial count followed by steady decline. The initial increase could be due to the utilization of nutrients by the microorganisms present (Tiquia, 2005). The decrease in count may be due to the depletion of nutrients in the waste, accumulation of toxic products and unfavorable growth environment (Kowalchuk et al., 1999). There are currently no reported values for an acceptable viable microbial count in finished compost. However, Atkinson et al. (1996), stressed that the microbial count should be low and should not contain significant quantities of viable pathogenic organisms. 
Table 1: Total viable bacterial and fungal counts of composting pig waste

\begin{tabular}{|c|c|c|c|c|}
\hline & \multicolumn{2}{|c|}{ Bacterial counts ( $\times 10^{3} \mathrm{cfu} / \mathrm{mL}$ ) } & \multicolumn{2}{|c|}{ Fungal count $\left(X 10^{2} \mathrm{cfu} / \mathrm{mL}\right)$} \\
\hline & Vermicomposted & Open heap & Vermicomposted & Open heap \\
\hline 0 & $9400 \pm 3.76$ & $46000 \pm 4.19$ & $260 \pm 2.77$ & $280 \pm 1.11$ \\
\hline 1 & $13000 \pm 0.58$ & $54000 \pm 11.81$ & $270 \pm 1.39$ & $290 \pm 1.39$ \\
\hline 2 & $79000 \pm 1.15$ & $74000 \pm 0.88$ & $100 \pm 2.01$ & $580 \pm 0.87$ \\
\hline 4 & $410 \pm 4.66$ & $670 \pm 1.00$ & $15 \pm 2.13$ & $560 \pm 0.44$ \\
\hline 6 & $3.8 \pm 0.87$ & $850 \pm 7.20$ & $16 \pm 0.59$ & $78 \pm 1.13$ \\
\hline 8 & $2.5 \pm 1.00$ & $81 \pm 1.15$ & $10 \pm 0.88$ & $99 \pm 1.15$ \\
\hline 10 & $0.91 \pm 0.03$ & $7.2 \pm 2.40$ & $5 \pm 1.09$ & $87 \pm 1.76$ \\
\hline 14 & $0.47 \pm 0.73$ & $7.6 \pm 2.31$ & $2 \pm 0.99$ & $75 \pm 0.78$ \\
\hline 18 & $0.29 \pm 0.02$ & $5.9 \pm 1.45$ & $5 \pm 1.15$ & $32 \pm 1.00$ \\
\hline 20 & $0.31 \pm 0.08$ & $0.38 \pm 0.15$ & $2 \pm 0.98$ & $10 \pm 2.01$ \\
\hline 24 & $0.26 \pm 0.16$ & $2.9 \pm 0.37$ & $2 \pm 1.00$ & $50 \pm 2.10$ \\
\hline 30 & $0.25 \pm 0.20$ & $2.3 \pm 0.19$ & $2.5 \pm 0.17$ & $58 \pm 1.26$ \\
\hline 40 & $0.23 \pm 0.20$ & $2.7 \pm 0.77$ & $2.1 \pm 0.11$ & $54 \pm 0.68$ \\
\hline
\end{tabular}

Note: $\quad$ Each value is the mean \pm standard error of the mean of the triplicate

Table2: Frequency of isolates recovered from composting pig waste

\begin{tabular}{lccc}
\hline Organisms & Vermicomposted & Open heap & Total \\
\hline Escherichia coli & $12(11.11 \%)$ & $13(7.83 \%)$ & $25(9.12 \%)$ \\
Klebsiella aerogenes & $3(2.78 \%)$ & $13(7.83 \%)$ & $16(5.84 \%)$ \\
Proteus mirabilis & $2(1.85 \%)$ & $3(1.81 \%)$ & $5(1.82 \%)$ \\
Pseudomonas aeruginosa & $13(12.04 \%)$ & $13(7.83 \%)$ & $26(9.49 \%)$ \\
Salmonella typhimurium & $1(0.93 \%)$ & $2(1.20 \%)$ & $3(1.09 \%)$ \\
Serratia mercescens & $2(1.85 \%)$ & $13(7.83 \%)$ & $15(5.47 \%)$ \\
Actinomycetes species & $13(12.04 \%)$ & $12(7.23 \%)$ & $25(9.12 \%)$ \\
Bacillus subtilis & $13(12.04 \%)$ & $13(7.83 \%)$ & $26(9.49 \%)$ \\
Clostridium perfringes & $6(5.56 \%)$ & $12(7.23 \%)$ & $18(6.57 \%)$ \\
Enterococcus faecalis & $3(2.78 \%)$ & $7(4.22 \%)$ & $10(3.65 \%)$ \\
Staphylococcus aureus & $2(1.85 \%)$ & $1(0.60 \%)$ & $3(1.09 \%)$ \\
Staphylococcus saprophyticus & $8(7.41 \%)$ & $2(1.20 \%)$ & $10(3.65 \%)$ \\
Candida albicans & $4(3.70 \%)$ & $10(6.02 \%)$ & $14(5.11 \%)$ \\
Saccharomyces cerevisiae & $5(4.63 \%)$ & $13(7.83 \%)$ & $18(6.57 \%)$ \\
Aspergillus flavus & $13(12.04 \%)$ & $13(7.83 \%)$ & $26(9.49 \%)$ \\
Mucor species & $4(3.70 \%)$ & $13(7.83 \%)$ & $17(6.20 \%)$ \\
Rhizopus nigricans & $4(3.70 \%)$ & $13(7.83 \%)$ & $17(6.20 \%)$ \\
\hline Total & $108(39.42 \%)$ & $166(60.58 \%)$ & $274(100 \%)$ \\
\hline
\end{tabular}

A total of 274 microbial isolates were recovered in this study (Table 2). Of these, the open heap yielded the highest, 166 (60.58\%), compared with vermicomposting, $108(39.42 \%)$. Enclosing the composting waste in a vessel helped to reduce the number and types of microbial isolates (Jagar et al., 1994). This may explain the result obtained in this study (Table 2). The result also shows that $P$. aeruginosa, $B$. subtilis and $A$. flavus were the most prevalent organisms isolated (9.49\% each), while $S$. typhimurium and $S$. aureus were the least isolated organisms (1.09\% each) (Table 2). The presence of Bacillus species, Aspergillus species and Pseudomonas species, has also been reported in compost (Ryckeboer et al., 2003). These organisms are ubiquitous and saprophytic and these may explain their high prevalence in this study. Though $S$. aureus is also ubiquitous, it is possible that nutrients and conditions in the compost did not favour its proliferation.
The process of composting has been divided into mesophilic, themophilic and curing stages (Droffner and Yamamoto, 1991). However, these three processes can only be followed senso stricto if heat is not allowed to escape (Kaneshiro et al., 1999) as it affects microbial succession.

For vermicomposting, all isolates were present at the start of the composting process, but only $P$. aeruginosa, Actinomycetes species, $B$. subtilis and $A$. flavus were found at the end and through out the composting period (Table 3). In the case of the open heaps, Actinomycetes species, $C$. perfringes and $S$. aureus were not present at the commencement of composting. They may have been introduced as environmental contaminants. E. coli, $K$. aerogenes, $P$. aeruginosa, $S$. marcescens, $B$. subtilis, $S$. cerevisiae, A. flavus, Mucor species and Rhizopus species were the isolates present from the beginning to 
Table 3: Microbial isolates in vermicomposted vessels at various composting period

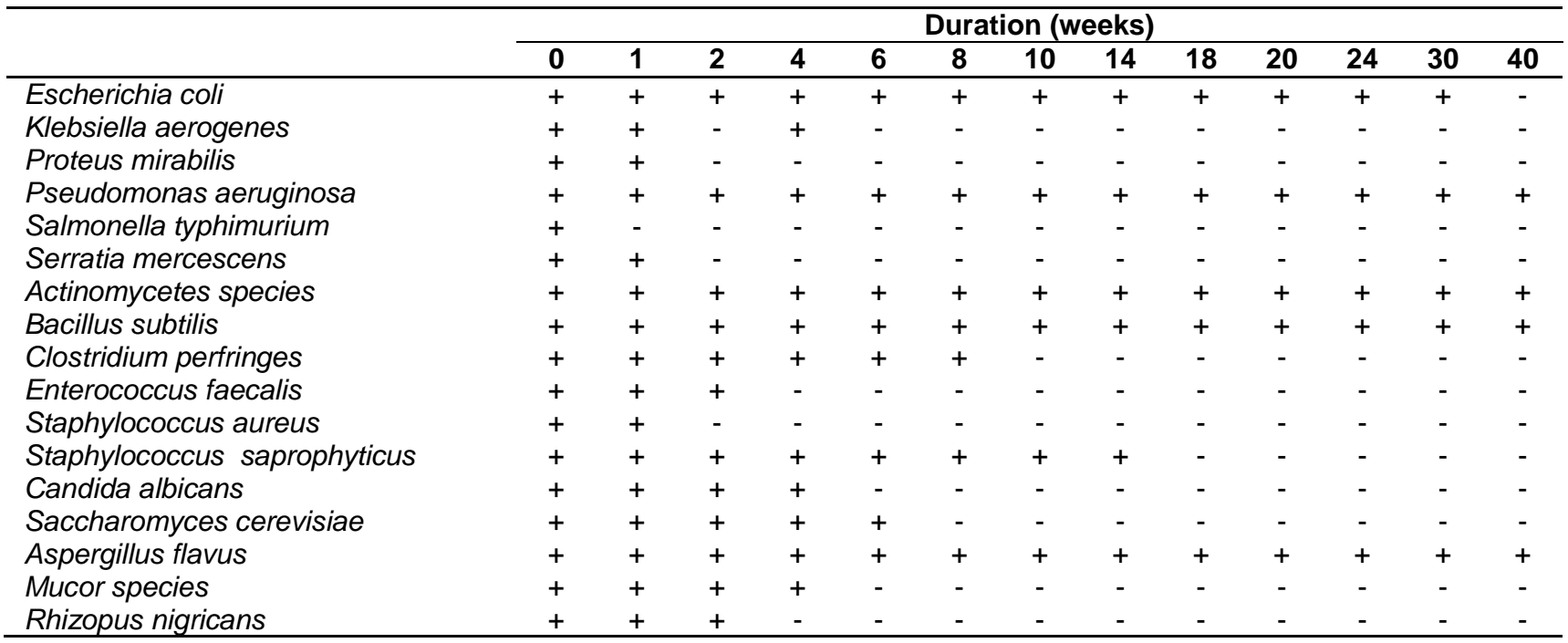

Key : $+=$ Isolated

$-=$ Not Isolated

Table 4: Microbial isolates in open heap at various composting periods

\begin{tabular}{|c|c|c|c|c|c|c|c|c|c|c|c|c|c|}
\hline & \multicolumn{13}{|c|}{ Duration (weeks) } \\
\hline & 0 & 1 & 2 & 4 & 6 & 8 & 10 & 14 & 18 & 20 & 24 & 30 & 40 \\
\hline Escherichia coli & + & + & + & + & + & + & + & + & + & + & + & + & + \\
\hline Klebsiella aerogenes & + & + & + & + & + & + & + & + & + & + & + & + & + \\
\hline Proteus mirabilis & + & + & + & - & - & - & - & - & - & - & - & - & - \\
\hline Pseudomonas aeruginosa & + & + & + & + & + & + & + & + & + & + & + & + & + \\
\hline Salmonella typhimurium & + & + & - & - & - & - & - & - & - & - & - & - & - \\
\hline Serratia mercescens & + & + & + & + & + & + & + & + & + & + & + & + & + \\
\hline Actinomycetes species & - & + & + & + & + & + & + & + & + & + & + & + & + \\
\hline Bacillus subtilis & + & + & + & + & + & + & + & + & + & + & + & + & + \\
\hline Clostridium perfringes & - & + & + & + & + & + & + & + & + & + & + & + & + \\
\hline Enterococcus faecalis & + & + & + & + & + & + & - & + & + & - & - & - & - \\
\hline Staphylococcus aureus & - & - & + & - & - & - & - & - & - & - & - & - & - \\
\hline Staphylococcus saprophyticus & + & + & - & - & - & - & - & - & - & - & - & - & - \\
\hline Candida albicans & + & + & + & + & + & + & + & + & - & + & + & - & - \\
\hline Saccharomyces cerevisiae & + & + & + & + & + & + & + & + & + & + & + & + & + \\
\hline Aspergillus flavus & + & + & + & + & + & + & + & + & + & + & + & + & + \\
\hline Mucor species & + & + & + & + & + & + & + & + & + & + & + & + & + \\
\hline Rhizopus nigricans & + & + & + & + & + & + & + & + & + & + & + & + & + \\
\hline
\end{tabular}

Key : $+=$ Isolated - = Not Isolated

the end of composting (Table 4). The succession of microorganisms obtained in this study does not follow a definite pattern (Tables 3 and 4). It has been reported that it is difficult to trace the succession of bacteria in a composting process (Droffner and Britton, 1995). However it has been recommended that Salmonella and E. coli be absent in animal waste compost for use as biofertilizer
(Schleiff and Dorn, 1997). Thus, the presence of $E$. coli at the end of composting in the open heap may make open heap compost unsuitable as biofertilizer. This, together with the lower number of isolates and microbial counts makes vermicomposted technique a better method of composting than the open heap technique. 
In conclusion, the study reveals reduction in microbial counts as well as microbial succession without a definite pattern. Vermicomposting technique is recommended in comparison to open heap technique due to the absence of pathogenic enteric organisms and lower microbial counts at the end of the composting period.

\section{REFERENCES}

Atiyeh, R. M., Arancon, N. Q., Edwards, C. A. and Metzger, J. D. (2002). The influence of earthworm processed pig manure on the growth and productivity of marigold. Bioresource Technology 81, 103-108.

Atkinson, C. J., Jones, D. D. and Gauthier, J. J. (1996). Biodegradability and microbial activities during composting of poultry litter. Poultry Science 75, 608617.

Barrow, G. I. and Feltham, R. K. A. (2003). Cowan and Steel's manual for the Identification of medical bacteria, ( $3^{\text {rd }}$ edition). Cambridge University Press, Cambridge. pp. 331.

Borken, W., Muhs, A. and Reese, F. (2002). Changes in microbial and soil properties following compost treatment of degraded temperate forest soils. Soil Biology Biochemistry 34, 403-412.

Cruickshank, R., Duguid, J. P., Marmion, B. P. and Swain, R. H. A. (1975). Medical microbiology $\left(12^{\text {th }}\right.$ edition). Churchhill Livingstone, New York. pp. 195200.

Droffner, M. L. and Britton, W. L. (1995). Survival of $E$. coli and Salmonella populations in aerobic thermophilic composts as measured with DNA gene probes. Zentralblatt fur Hygiene und Umweltmedizin 197, 387-397.

Droffner, M. L. and Yamamoto, N. (1991). Isolation of thermotolerant mutants of $B$. subtilis and $B$. pumilus and transformation of the thermophilic trait to mesophilic strains. Journal of General and Applied Microbiology 131, 2791-2794.

Guibileo, L., Sarti, A. M., Bianchi, L. A., Calcaterra, E. and Colombi, A. (1998). Review of risks of biological agents and preventive measures to safeguard the health of compost production workers. Medical Law Review 89, 301-315.

Inbar, I., Hadar, Y. and Chen, Y. (1993). Recycling of cattle manure, the composting process and characterization of maturity. Journal of Environmental Quality 22, 857-863.

Ishii, K., Fukui, M. and Takii, S. (2000). Microbial succession during a composting process as evaluated by denaturing gradient gel electrophoresis analysis. Journal of Applied Microbiology 89, 768777.

Jagar, E., Rupen, H. and Zeschmarlahi, B. (1994). Microbiological quality of compost with special regard to disposable diapers. Zentralblatt Hygiene Umweltmedizin 196, 245-257.

Jarvis, A. S., McFarland, V. A. and Honeycutt, M. E. (1988). Assessment of the effectiveness of composting for the reduction of toxicity and mutagenicity of explosive contaminated soil. Exotoxicology and Environmental Safety 39, 131-135.

Kaneshiro, I., Kuo, I. M. and Nakamura, I. K. (1999). Conversion of unsaturated fatty acids by bacteria isolated from compost. Current Microbiology 38, 250255.

Kowalchuk, G. A., Naomenko, Z. S., Derika, P. I., Felske, A., Stephen, J. R. and Arkhipchenko, I. A. (1999). Molecular analysis of ammonia-oxidizing bacteria of the beta subdivision of the class proteobacteria in compost and composted materials. Applied and Environmental Microbiology 65, 396-403.

Lodder, J. (1971). The yeasts - a taxonomic study. North Holland publishing company, Amsterdam. pp. 1385.

Ogefere, H. O. (2007). Microbiological and physicochemical studies of composting pig wastes. Ph.D. thesis. University of Benin.

Rippon, J. W. (1974). Medical mycology: The pathogenic fungi and pathogenic actinomycetes. W. B. Saunders, London. pp. 174.

Ryckeboer, J., Mergaert, J., Coosemans, J., Deprins, K. and Swing, J. (2003). Microbiological aspects of biowaste during composting in monitored compost bin. Journal of Applied Microbiology 94, 127-137.

Schleiff, G. and Dorn, W. (1997). Hygienic bacteriologic evaluation of methods for production of dry poultry faeces manure. Zentralblatt fur Hygiene und Umweltmedizin 199, 475-495.

Tiquia, S. M. (2005). Microbiological parameters as indicators of compost maturity. Journal of Applied Microbiology 99, 816-828.

University System News (1994). Four universities test run human waste composting Facility. University System News 4, 8. 